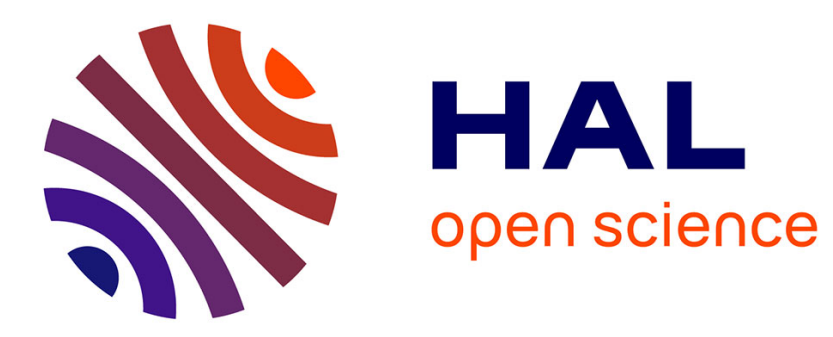

\title{
Discontent with taxes and the timing of taxation: experimental evidence
}

\author{
Radu Vranceanu, Angela Sutan, Delphine Dubart
}

\section{To cite this version:}

Radu Vranceanu, Angela Sutan, Delphine Dubart. Discontent with taxes and the timing of taxation: experimental evidence. 2019. hal-01282724v2

\section{HAL Id: hal-01282724 \\ https://essec.hal.science/hal-01282724v2}

Preprint submitted on 11 Oct 2019

HAL is a multi-disciplinary open access archive for the deposit and dissemination of scientific research documents, whether they are published or not. The documents may come from teaching and research institutions in France or abroad, or from public or private research centers.
L'archive ouverte pluridisciplinaire HAL, est destinée au dépôt et à la diffusion de documents scientifiques de niveau recherche, publiés ou non, émanant des établissements d'enseignement et de recherche français ou étrangers, des laboratoires publics ou privés. 


\section{ESSEC \\ BUSINESS SCHOOL}

\section{DISCONTENT WITH TAXES AND}

THE TIMING OF TAXATION:

EXPERIMENTAL EVIDENCE

RADU VRANCEANU, ANGELA SUTAN, DELPHINE DUBART

ESSEC RESEARCH CENTER

WORKING PAPER 1602

VERSION 2, OCTOBER 2019 


\title{
Discontent with taxes and the timing of taxation: Experimental evidence
}

\author{
Radu Vranceanu*, Angela Sutan, Delphine Dubart ${ }^{\ddagger}$
}

\begin{abstract}
This paper reports experimental results from a linear sanction cost variant of the power-to-take game, with implications for tax collection policies. This framework allows to compare a pay-as-you-earn (PAYE) tax collection system with an ex-post tax collection system in which payroll taxes are levied at the end of the fiscal year. In the second system, taxpayers might develop a feeling of income ownership, and express higher dissatisfaction if the government appropriates a part of it. In our data, dissatisfaction with taxation, as proxied by the sanction in the power-to-take game, is significantly higher in the ex-post tax collection system compared with the PAYE system. Communication opportunities are associated with lower sanction rates, yet the communication channel is not used extensively by participants.

Keywords: Tax collection system, Pay-As-You-Earn, Endowment effect, Power-to-take game, Experiments.

JEL Classification: C91; H26; D01

$* * *$

Insatisfaction avec l'impôt et séquence temporelle du prélèvement : Une étude expérimentale

\section{Résumé}

L'article présente les résultats d'une expérience basée sur une variante du jeu « power-to-take » avec des implications concernant les modalités de prélèvement de l'impôt sur le revenu. L'étude compare le système d'impôt à la source avec un système a posteriori, dans lequel l'impôt est prélevé bien après le moment où le contribuable a perçu le revenu brut. Dans cette seconde situation, les contribuables peuvent développer un sentiment de propriété du revenu total, et ressentir un mécontentement plus important, à taux d'imposition identique. Nos résultats indiquent que l'insatisfaction associée à l'impôt, mesurée par la sanction imposée sur l'agent qui prélève, est significativement plus importante dans le système a posteriori comparée au prélèvement à la source. La communication vers le contribuable permet de réduire le taux de sanction, mais les participants n'exploitent pas vraiment cette opportunité.
\end{abstract}

Mots-clés : Fiscalité, Impôt sur le revenu, Prélèvement à la source, Effet de dotation, Expérience.

\footnotetext{
*ESSEC Business School and THEMA, 1 Av. Bernard Hirsch, PB50105, 95021 Cergy, France. E-mail: vranceanu@essec.edu

${ }^{\dagger}$ Corresponding author. Univ. Bourgogne Franche-Comte, Burgundy School of Business-CEREN, 9, Rue Sambin, 21000 Dijon, France. E-mail: angela.sutan@bsbeducation.com.

${ }^{\ddagger}$ ESSEC Business School, Experimental Lab, 1 Av. Bernard Hirsch, PB50105, 95021 Cergy, France. E-mail: dubart@essec.edu.
} 


\section{Introduction}

One important institutional characteristic of taxation systems is the time sequence of the tax collection. The large majority of Western countries run a system in which taxes are withheld at the source of income and at the time when income is generated. Applied to the labor income tax, the "pay-as-you-earn" (PAYE) tax is withheld from an employee's wages by his/her employer who directly sends the collected amount to the appropriate taxing authority. In this system, employees receive the tax and net income information at the same time. In the alternative "ex-post" tax collection system, employees earn a gross income every month, then pay the accumulated payroll tax at a later time, normally at the end of the year. Among developed countries, only Switzerland (FDF [2016]) and Singapore continue to use the latter. After vivid discussions that lasted for three years, France finally adopted the PAYE system as of January 1st, 2019.

The main research question of this paper is to study whether dissatisfaction with taxation depends on whether taxes are collected at the same time when the income is earned (PAYE tax collection system), or after the income is earned (ex-post tax collection system). ${ }^{1}$

Taking stock on the prospect theory (Kahneman and Tversky [1979]), Kahneman et al. [1990] argued that people express attachment to things they own, and would ask a premium over the market value of a similar good to give up their good. ${ }^{2}$ Several studies (mostly in psychology) argued that this "endowment effect" would also apply to lotteries and income ownership (Yechiam et al. [2017]), as people quickly adopt the higher wealth level as the status quo (Kirchler and Hoelzl [2018]) or associate higher income with higher self-esteem (Morewedge and Giblin [2015]). In the taxation context, for similar tax burdens, different tax collection systems can generate different perceptions with respect to income ownership. If in the ex-post tax collection system, you feel that the government is "confiscating" income from you, while in the PAYE tax collection systems you only feel that you own what is left after the tax, then the satisfaction attached to every euro

\footnotetext{
1 Kirchler [2007] notes that, in addition to individual characteristics, negative attitudes toward taxes can be influenced by the situational and institutional context, such as the complexity of the tax code, information dissemination, involvement of taxpayers in building tax spending objectives, personal service provision by tax authorities, communication, and the design and structure of tax forms.

2 Recently there has been a considerable amount of debate whether the observed differences in willingness to pay (to obtain a good) and willingness to accept (to renounce to a good) truly capture the endowment effect or some computing biases and learning effects (Plott and Zeiler [2007], Fehr et al. [2015]).
} 
left in your pocket should be higher in the latter system. Furthermore, income taxes are more salient in the ex-post tax collection system compared to the PAYE system, which could further enhance dissatisfaction with taxation in the Ex-Post system (Chetty et al. [2009]).

To compare dissatisfaction with taxation between the two systems, we develop a variant of the "power-to-take" game introduced by Bosman and van Winden [2002]. ${ }^{3} \quad$ In the original game, there are two players, the "taker" and the "responder". At the onset of the experiment, the responder receives an endowment. Then, the taker decides on the take rate to be applied to the responder's endowment. In the second stage, the responder chooses a destroy rate that will reduce the payoffs of both agents. The destroy rate can been interpreted as a measure of the responder's negative emotions toward the taker's behavior (Galeotti [2015]). Bosman and van Winden [2002] argued that the power-to-take has a natural application to taxation issues, as "the take authority can be regarded, in an admittedly simplistic way, as a majority coalition (government) that, by means of taxation, can appropriate a part of the endowment of the minority (the responders)". As reported by van Winden [2015], in the power-to-take game, takers claim, on average, approximately $60 \%$ of the responder's resources while responders destroy approximately $20 \%$ on average. The average rate is hiding substantial polarization of choices, with many responders destroying all or nothing. The higher the take rate is, the higher the sanction. However, as noted by Galeotti [2015], in this game the fine-to-tax rate is decreasing in the tax rate; thus, it may be tempting to punish when the tax rate is high only because it is relatively cheaper to punish. To eliminate this demand-forpunishment effect, in this paper we introduce a variant of the power-to-take game with a linear punishing cost (Fehr and Gächter [2000]; Falk and Fischbacher [2005]).

There is Agent A who receives an endowment (the "taxpayer") and Agent B (the "tax authority") who can take some of the Agent A's endowment (this "tax" being an earning for Agent B himself). ${ }^{4} \quad$ In the benchmark case, referred to as the "ex-post system", Agent A receives an income and then agent B levies the tax. In the other case, referred to as the "PAYE system", Agent B first claims the tax, then Agent A receives the difference. In both cases, at the last stage,

\footnotetext{
3 Experimental research using the power-to-take game is flourishing. See for instance: Bosman et al. [2005] Ben-Shakhar et al. [2007], Reuben and van Winden [2008], Sutter [2009], Galeotti [2013], Bosman et al. |2017].

4 In the experiment, we use neutral language and avoid the labels "tax payer' and "tax authority".
} 
Agent A can impose a sanction on Agent B. The analysis will focus on factors that explain the sanction rate, viewed as a measure of the taxpayers' discontent with taxation. Taking into account the endowment effect as documented before, we conjecture that, for similar tax burdens, sanction rates are lower in the PAYE treatments compared to the ex-post treatments.

Taxation literature pointed out that dissatisfaction with taxation can be contained if, by means of efficient communication, the government manages to convince taxpayers of the usefulness or moral justification of the tax (Kirchler [2007], Hallsworth et al. [2014]). ${ }^{5} \quad$ To analyze whether communication has an impact on the sanction, we also implement sessions in which Agent B (the tax authority) can send a short message to Agent A. All else equal, we conjecture that positive communication should help in accepting a higher tax.

A fifth independent treatment will let the computer decide on the transfer from Agent A to Agent B. The objective of this test is to investigate whether the sanction is backed by a retaliation motive, or mere anger with a transfer of income to another player.

In brief, the results show that dissatisfaction with taxation, as proxied by the sanction in the power-to-take game, is significantly higher in an ex-post taxation system compared with the PAYE system.

Robben et al. [1990] studied the withholding tax system, focusing on the end-of-the-year adjustment bill. In line with the endowment effect theory, in their data too, taxpayers who were facing the prospect of an additional tax payment were more prone to cheat, compared to those who expected a rebate. Christian and Alm [2014] argued that higher well-being as experienced by an individual when he acts according to high standards of conduct, can be associated with higher tax compliance. The OECD [2009] experts argued that withholding arrangements would reduce the incidence of unpaid taxes.

It must be acknowledged that our design does not allow taking into account two important characteristics of real-life tax systems. First, the experiment focuses on the confiscatory dimension of taxation, without considering the purpose dimension, or the personal benefit individuals

\footnotetext{
${ }^{5}$ In a different framework, Fischbacher and Utikal [2013] have shown that merely by sending convincing apologies, receivers are less eager to retaliate.
} 
associate with the act of paying taxes. Second, the act of paying taxes has a social dimension, as an individual's attitude toward taxes depends on the attitude of other people in a similar role with whom the individual interacts (Weigel [1987], Onu and Oats [2015], van Winden [2015]). While our design allows for strategic interaction between the taxpayer and the tax authorities, the relationship between the individual and the reference group of taxpayers has not been taken into account.

The next section presents the design of the experiment. Section 3 presents the results, the last section is our conclusion.

\section{Design of the experiment}

Experimental sessions were performed at the LESSAC Experimental Lab; all subjects were recruited from the student population of the Burgundy School of Business (France), who answered an advertisement for paid decision experiments. The experimental sessions were organized in October 2015 with a total of 165 subjects. Interaction was strictly anonymous. Participants made decisions on a computer screen and could not establish eye contact with one another. The data collection was computerized; the program was developed using z-Tree (Fischbacher 2007). At the beginning of the experiment, participants were assigned a role, Agent A or Agent B, which did not change throughout the experiment. Participants were requested to play the same game for three identical rounds; nonetheless, pairs were rematched after each round (stranger design), and participants knew it. The compensation was provided in cash at the end of the session. Compensation included a 5 euros show-up fee and the gain of one of the three rounds chosen at random. On average, participants earned 8 euros per 35 minute session.

We ran four key treatments with a 2x2 structure, varying (1) the time sequence of collecting the tax and (2) the possibility to send a message (see Table 1). Students participating in one treatment could not participate in another treatment. We introduce here the key elements (detailed instructions are available in the online Appendix A). The key manipulation pertains to the ownership of the income that can differ whether the taxes are collected at the same time when the income is earned, or at a later time, once that individuals might have developed strong income 
ownership feelings.

\begin{tabular}{|l|l|l|}
\hline & Ex-post & PAYE \\
\hline Communication: impossible & T1 $(30$ pairs $)$ & T2 $(36$ pairs $)$ \\
\hline Communication: possible & T3 (36 pairs) & T4 $(36$ pairs $)$ \\
\hline
\end{tabular}

Table 1: Main treatments

Treatment 1 (T1) - Ex-post tax collection system / no communication

Step 1. At the beginning of each round, the computer draws an ECU-denominated income (experimental currency units) as an integer $Y$ from the $[50,100]$ set. The exchange rate was 10 ECUs $=1 €$. The random draw has a uniform distribution.

Step 2. Agent A is informed that he earned this amount. He is also invited to make a guess $G[T]$ regarding the amount of $T$ that Agent B will take from him at the next step. For his guess, he will receive a compensation that is an increasing function in the precision of the guess, with a maximum of 20 ECUs. ${ }^{6}$

Step 3. It is the turn of Agent B to make a decision. He can take $T$ from Agent A, with $T \in[0, Y]$. Before applying the tax, he must make an incentivized guess $G[S]$ regarding the sanction, $S$, that Agent B would impose on him. ${ }^{7}$

Step 4. In this last stage, Agent A can impose sanction $S$ on Agent B, with $S \in[0, T]$. The sanction corresponds to destroyed income of Agent B; it is not an income for Agent A; actually, each ECU of sanction will cost 0.20 ECUs to Agent A .

These steps are repeated for three identical rounds with changing pairs. After each round, the two players learn their gain for that round. The gain of Agent B is $(T-S)$, to which will be added the payoff for the guess of the sanction. The final gain of Agent A is $(Y-T-0.2 S)$, to which will eventually be added the payoff for his guess of the tax.

Treatment 2 (T2) - PAYE tax collection system / no communication

Treatment 2 is nearly similar to Treatment 1 , with the difference that, once that the computer has drawn the endowment $Y$, Agent B learns this amount and can immediately collect tax $T$. Thus, Agent A simultaneously observes $Y, T$, and $(Y-T)$. He no longer has the opportunity to

\footnotetext{
6 The payoff is determined by the formula $20 /\left[1+(T-G[T])^{2}\right]$, where a maximum gain of 2 euros is obtained for an exact forecast, and it tends toward zero as errors increase.

7 The payoff for the guess is $20 /\left[1+(S-G[S])^{2}\right]$.
} 
make a guess on what would be the tax, because the tax has already been levied. The decision steps are:

Step 1. At the beginning of each round, the computer draws at random an ECU-denominated income as an integer, $Y$, from the $[50,100]$ uniform distribution.

Step 2. Agent B learns this amount, and can collect a tax $T \in[0, Y]$. Before, he must make an incentivized guess $G[S]$ regarding sanction $S$ that Agent A will impose on him at the end of the round.

Step 3. Agent A learns $Y, T$ and his endowment $[Y-T]$. He can impose sanction $S$ on Agent B, with $S \in[0, T]$. Each ECU of sanction will cost 0.20 ECUs to Agent A.

Treatment 3 (T3) - Ex-post tax collection system / with communication

This treatment is similar to Treatment 1 with the difference that now Agent B can send a maximum 80-character message to player A "related to his decisions in the game". Player A views the message at the same time he learns the tax and before he decides on the sanction.

Treatment 4 (T4) - PAYE tax collection system / with communication

This treatment is similar to Treatment 2 with the opportunity for B to send a short message (as in T3).

After each of the three rounds, players learn their gain for the round. For each round, the gain of Agent B is $(T-S)$ plus the payoff for the guess of the sanction, and the final gain of Agent A is $(Y-T-0.2 S)$.

To investigate the role of responsibility attribution on discontent with taxation, we also ran a fifth treatment (T5) with 27 subject pairs in which the computer decided the amount of $T$ to be transferred from Agent A to Agent B in a PAYE sequence. In this treatment, once that income $Y$ is drawn from the uniform distribution [50,100], the computer draws $T$ at random from the uniform distribution $[0, Y]$, then attributes the difference $(Y-T)$ to Agent A, and tax $T$ to Agent B. As before, Agent A can impose a costly sanction, $S$, on Agent B.

In treatments $\mathrm{T} 1$ and $\mathrm{T} 3$ we asked subjects to make a guess of the tax rate while no guess is possible in $\mathrm{T} 2$ and $\mathrm{T} 4$ since the subject simultaneously learns his/her income and the tax; this might have raised the salience of the tax in the ex-post treatment. Ideally, we should also have 
collected data for $\mathrm{T} 1$ and $\mathrm{T} 3$ without the guess. On the other hand, in a real life taxation context, taxes in the ex-post system have higher salience as they appear as a large amount to be paid at the end of the year, which might back our empirical strategy.

\section{Results}

We present descriptive statistics for the five treatments in the online Appendix B (Table 9). The key variables for each pair and period are the income $Y$, the $\operatorname{tax} T$, and the sanction $S$, with $S \leq T \leq Y$. We also provide information about the guess of $S$, and, for the ex-post treatments only, for the guess of $T$.

If we briefly analyze the behavior of Agent B (the "tax authority"), we notice that the mean tax-to-income rate $(T / Y)$ is higher in the ex-post treatments compared to the PAYE treatments (Table 2). This difference is significant $(\mathrm{p}<0.01)$ in the treatments in which communication is not allowed ( $\mathrm{T} 1 \mathrm{vs}$. $\mathrm{T} 2)$, yet it narrows to nonsignificant levels $(\mathrm{p}=0.25)$ when communication is allowed (T3 vs. T4). ${ }^{8}$ A panel data regression model (in the online Appendix C, Table 10) corroborates these findings.

\begin{tabular}{|l|l|l|}
\hline & Ex-post & PAYE \\
\hline Communication: impossible & T1: $0.68(0.03)$ & T2: $0.53(0.03)$ \\
\hline Communication: possible & T3: $0.62(0.03)$ & T4: $0.57(0.02)$ \\
\hline
\end{tabular}

Table 2: Mean tax rate by treatment (s.e. within parantheses)

Data in Table 3 show that, on average, Agents B expect a higher sanction rate in the ex-post treatments compared to PAYE treatments, something that could prompt them to impose higher taxes in the first place. ${ }^{9} \quad$ A comparison of actual and guessed sanction rates (in the Appendix C, table 11) reveals that expectations are accurate on average, although substantial variability can be observed in individual data (with a standard deviation of the guess error rate of 0.50).

As indicated in the introduction, our main research question is the effect of the tax collection system on the satisfaction/dissatisfaction of the taxpayer. Therefore, this analysis focuses on the

\footnotetext{
8 Throughout the text, for mean comparisons, we will report p-values based on the F-statistic in repeatedmeasures ANOVA (treatment effect).

${ }^{9}$ In 46 out of 414 observations, the guessed sanction was larger than the tax, in contradiction with the constraint $S \leq T$ stated in the instructions. Mean values in Table 3 do not include these outliers.
} 


\begin{tabular}{|l|l|l|}
\hline & Ex-post & PAYE \\
\hline Communication: impossible & T1: $0.59(0.04)$ & T2: $0.30(0.04)$ \\
\hline Communication: possible & T3: $0.42(0.04)$ & T4: 0.26(0.04) \\
\hline
\end{tabular}

Table 3: Mean guessed sanction rate by treatment (s.e. within parantheses)

behavior of Agent A. The latter can impose a fine on the "taxing agent". Because the sanction involves a cost for the punisher, it can be interpreted as a measure of the dissatisfaction with the tax. Since the tax is capped by the income $(T \leq Y \leq 50)$, and the sanction is capped by the tax $(S \leq T)$, in the following, we will use the sanction rate $S / T$ as the relevant measure of dissatisfaction. In 11 out of 414 occurrences, Agents A imposed no tax on Agents B, so the sanction rate was mechanically set to zero. Because they are generated by a constrained choice, we will treat these $0 / 0$ ratios as missing values. In line with standard findings in other power-to-take experiments, in a substantial number of cases Agents A made extreme choices (zero sanction in $40.2 \%$, and maximal sanction in $17.4 \%$ of the 403 observations).

Figure 1 represents the cumulative distributions of the sanction rates in the ex-post and PAYE systems (data were pooled with respect to communication opportunities). The ex-post distribution exhibits first-order stochastic dominance over the PAYE distribution: the frequency of low sanction rates is higher in the PAYE system.

Table 4 presents the mean sanction-to-tax rates $(S / T)$ by treatment.

\begin{tabular}{|l|l|l|}
\hline & Ex-post & PAYE \\
\hline Communication: impossible & T1: $0.52(0.04)$ & T2: 0.30 (0.03) \\
\hline Communication: possible & T3: $0.37(0.04)$ & T4: $0.22(0.03)$ \\
\hline
\end{tabular}

Table 4: Mean sanction rate by treament (s.e. within parantheses)

In line with the distributions in Figure 2, we notice that mean sanction rates are much higher in the ex-post treatment, compared to the PAYE treatment both in the without-communication condition $(0.52$ vs. $0.30 ; \mathrm{p}<0.01)$ and the with-communication condition $(0.37$ vs. $0.22 ; \mathrm{p}<0.01)$.

Data in Table 4 also show that in the ex-post treatments, the mean sanction rate is lower when communication is possible compared to the cases where communication is not possible (0.37 vs. $0.52 ; \mathrm{p}<0.01)$. The mean sanction rate is also lower in the PAYE system, albeit the difference does not appear to be significant $(\mathrm{p}=0.24)$. 


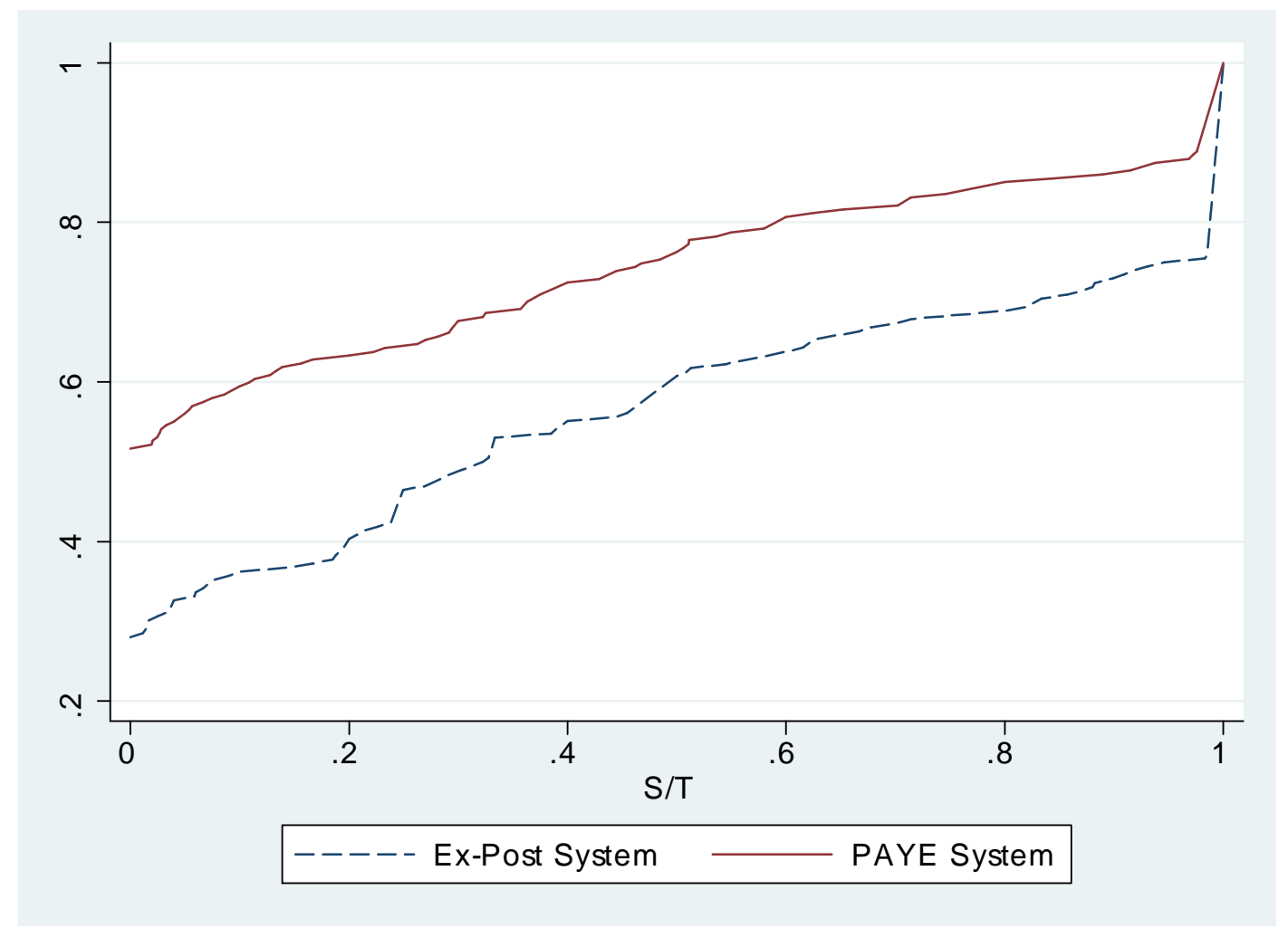

Figure 1: The cumulative distribution of the sanction rate by tax collection system

If individuals prefer more income to less, then higher tax rates should determine a higher discontent with taxation, and higher sanction rates. Even if individuals acknowledge that taxes are necessary to finance the production of public goods, a tax rate above what might be perceived as "fair" could entail higher dissatisfaction and would lead to higher sanction rates, in particular if the tax authority does not communicate on the purpose of the tax. Figure 2 displays on the horizontal axis the tax rate imposed on Agent A, and the sanction rate he/she applied on Agent $\mathrm{B}$, in each of the two tax collection systems. The two scatter diagrams display a high dispersion of choices, from which it is difficult to infer a clear pattern.

Regression analysis allows checking whether the former results hold when controlling for the tax rate.

The dependent variable is the sanction rate $S / T$ imposed by participant $i$ (Agent A) at period $t$ (with $t=1,2,3)$. We create four treatment indicator variables, DTk, with $k=(1,2,3,4)$, each 


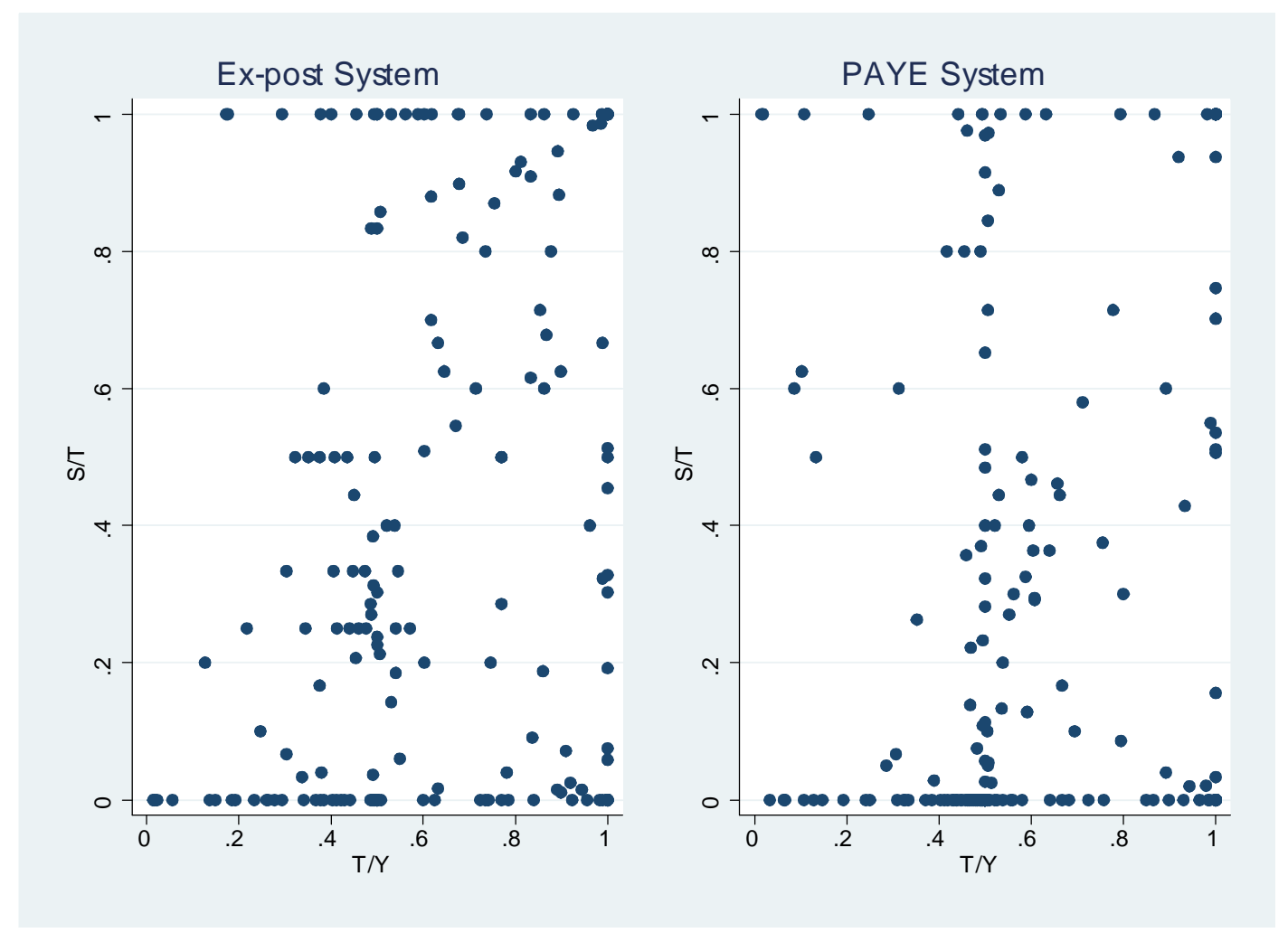

Figure 2: Sanction rate vs. tax rate by tax collection system

taking the value of 1 if treatment $=k$ and 0 otherwise. ${ }^{10}$ We also included period dummies, $P 1$, $P 2$ and $P 3$. Another important covariate is the tax rate $T / Y$.

As already mentioned, in treatments T3 and T4, Agents B could send 80-character messages to Agents A; they sent such messages in $56 \%$ of the possible occurrences. The indicator variable, DI, will take the value 1 if a message has been sent by Agent B to Agent A, and 0 otherwise (therefore, it is zero in treatments $\mathrm{T} 1$ and $\mathrm{T} 2$, and if a message was not issued in $\mathrm{T} 3$ and $\mathrm{T} 4$ ). ${ }^{11}$

Table 5 presents the results of random effects, panel data regression models which account that every individual $i$ in the role of Agent A made three choices, at three distinct periods. The benchmark is the sanction rate in T1 (Ex-Post, no communication), as DT1 is omitted (and so is P1).

From the descriptive statistics, combined with regression analysis, we can emphasize three

\footnotetext{
${ }^{10}$ For instance, DT1 takes the value of 1 for observations collected in treatment 1 , and 0 otherwise.

${ }^{11}$ We read the messages and coded the content: $47.9 \%$ of the messages issue a call for coordination or "moral" behavior, $26.4 \%$ of the messages aim to create a positive link (for instance display a smiley icon), $6.6 \%$ are apologetic, and the rest are ironic or meaningless.
} 


\begin{tabular}{|l|l|l|l|l|}
\hline & Model 1 & Model 2 & Model 3 & Model 4 \\
\hline DT2 & $-0.223^{* * *}(0.06)$ & $-0.224^{* * *}(0.06)$ & $-0.167^{* * *}(0.06)$ & $-0.167^{* * *}(0.06)$ \\
\hline DT3 & $-0.152^{* * *}(0.06)$ & $-0.152^{* * *}(0.06)$ & $-0.127^{* *}(0.06)$ & $-0.141^{* *}(0.06)$ \\
\hline DT4 & $-0.299^{* * *}(0.06)$ & $-0.299^{* * *}(0.06)$ & $-0.257^{* * *}(0.06)$ & $-0.274^{* * *}(0.06)$ \\
\hline P2 & - & $-0.001(0.05)$ & $-0.032(0.04)$ & $-0.032(0.04)$ \\
\hline P3 & - & $0.013(0.05)$ & $-0.032(0.04)$ & $-0.032(0.04)$ \\
\hline Tax rate & - & - & $0.434^{* * *}(0.07)$ & $0.435^{* * *}(0.07)$ \\
\hline DI & - & - & - & $0.028(0.05)$ \\
\hline Constant & $0.522^{* * *}(0.04)$ & $0.517^{* * *}(0.05)$ & $0.244^{* * *}(0.07)$ & $0.243^{* * *}(0.07)$ \\
\hline R2_btw & 0.169 & 0.169 & 0.238 & 0.241 \\
\hline Nb. obs. & 403 & 403 & 403 & 403 \\
\hline Legend: ${ }^{* *}$ significant at 1\%; ${ }^{* *}$ significant at 5\%; Std. err. within parentheses. \\
\hline
\end{tabular}

Table 5: The Sanction Equation

results:

1. The sanction rate is significantly higher in the ex-post tax collection system compared to the PAYE system, even when controlling for the average tax rate.

Indeed, the coefficient on T2 is negative, significant and large; it reveals that in the withoutcommunication condition, the sanction rate is lower (the benchmark is T1) in the PAYE system. In addition, the coefficient on DT4 is lower than the coefficient of DT3 in all four models, showing that in the with-communication condition, the same effect is observed (largest $\mathrm{p}=0.015$ across the 4 models; Wald test).

2. Sanctions tend to be weaker in treatments in which communication is allowed compared with treatments without communication.

Here, also the coefficient on DT3 is negative, indicating that in the ex-post condition, communication reduces the sanction; also, the (negative) coefficient of DT4 is lower than the coefficient of DT2, revealing a similar effect of communication opportunities in the PAYE condition (albeit not significantly different, $\mathrm{p}=0.18$ in models 1 and 2 , and 0.09 in models 3 and 4 ; Wald test).

The "effective message" dummy DI is not significant, and, when including it into the regression model (Model 4), coefficients of the treatment dummies do not change much. This would suggest that the possibility to communicate is more important than the messages themselves, which were very short by design and maybe not informative enough. ${ }^{12}$

3. The sanction rate is increasing in the tax rate.

12 A regression model with observations only from the communication treatments (T3 and T4) reveals no effect of actual communication on the sanction rate. 
The coefficient of the tax rate in models 3 and 4 is positive and significant. All things equal, raising the tax rate by 10 percentage points would increase the sanction rate by 4.3 percentage points.

The design of the experiment allowed us to carry out two complementary analyses.

Bosman and van Winden (2002) showed that difference between the take rate and the expected take rate has a better explanatory power on the sanction rate than the mere take rate. In our experiment, Agents A in the ex-post condition (T1 and T3) could make a guess of the tax rate as charged by Agents B. In the aggregate, the guess is correct (Table 6), but there is substantial variability in the individual data (with a standard deviation in the guessing error of 0.37).

\begin{tabular}{|l|l|l|}
\hline & Treatment 1 & Treatment 3 \\
\hline $\mathrm{T} / \mathrm{Y}$ & $0.68(0.03)$ & $0.62(0.03)$ \\
\hline Guess of T/Y & $0.68(0.03)$ & $0.61(0.02)$ \\
\hline Difference tax-guessed tax & $0.00(0.04)$ & $0.01(0.03)$ \\
\hline
\end{tabular}

Table 6: Mean tax rate and guessed tax rate by treatment (s.e. within parantheses)

Table 7 reports results from a random effects, panel regression model with the sanction rate $S / T$ as the dependent variable, similar to models in Table 5. We use observations from T1 and T3.

\begin{tabular}{|l|l|l|}
\hline & Model 1 & Model 2 \\
\hline DT3 & $-0.122^{* *}(0.05)$ & $-0.157^{* * *}(0.05)$ \\
\hline Tax rate & $0.51^{* * *}(0.10)$ & - \\
\hline Tax rate - Guess of tax rate & - & $0.395^{* * *}(0.07)$ \\
\hline Constant & $0.172^{* *}(0.08)$ & $0.520^{* * *}(0.04)$ \\
\hline R2_between & 0.156 & 0.187 \\
\hline Nb. obs. & 196 & 196 \\
\hline Legend: *** significant at 1\%; ${ }^{* *}$ significant at 5\%; Std. err. within parentheses. \\
\hline
\end{tabular}

Table 7: Sanction equation: The role of the expected tax rate

Our results corroborate those in Bosman and van Winden [2002], i.e., the difference between the tax rate and the expected tax rate appears to be a better explanatory factor of the sanction rate.

Finally, complementary treatment T5 is a variant of T2 (i.e., a PAYE mechanism, where the tax is collected before the income is attributed to Agent A), with the important difference that the computer selected the number of ECUs to be transferred from Agent A to Agent B. In this 
context, Agent A cannot attribute the responsibility of the tax (a loss for himself) to Agent B, although the "tax" ultimately becomes an income for the latter.

Table 8 presents the mean tax and sanction rates in treatments T2 and T5.

\begin{tabular}{|l|l|l|}
\hline & T2 (PAYE, Agent B chooses T) & T5 (PAYE, computer chooses T) \\
\hline Nb. obs. & 108 & 81 \\
\hline T/Y & $0.53(0.03)$ & $0.51(0.03)$ \\
\hline S/T & $0.30(0.03)$ & $0.25(0.04)$ \\
\hline
\end{tabular}

Table 8: Mean tax and sanction rates in comparison T2 vs. T5 (s.e. within parantheses)

The difference between mean tax rates is not statistically significant $(p=0.18)$, nor is the difference between mean sanction rates $(\mathrm{p}=0.50) .{ }^{13}$

This might suggest that sanctions in this experiment are essentially driven by negative emotions related to the income loss, independent of the responsibility attribution process and the retaliation motive. That negative emotions are an important motive for punishment in the power-to-take game has already been emphasized by Bosman and van Winden (2002) and Galeotti (2015).

\section{Conclusion}

We argued that a PAYE tax collection system might contain the income endowment effect and therefore diminish taxpayers' discontent with taxation compared to the ex-post system. To test this assumption, we implemented an original experiment as a linear sanction variant of the powerto-take game (Bosman and van Winden [2002]). In the last stage of the game, the taxpayer (Agent A) can impose a sanction on the tax authority (Agent B). Because the sanction costs something to the punisher, it can be viewed as a measure of his dissatisfaction with the action of Agent B.

As expected, the tax rate is positively related to the sanction rate. Data from the ex-post treatments revealed that the unexpected tax is a strong determining factor of the sanction rate.

The key result of the analysis is to show that the PAYE system, in which taxes are levied before the taxpayer can develop strong income ownership sentiments, generates lower dissatisfaction with taxation than the ex-post system. This behavioral argument would back the decision of the French

\footnotetext{
13 In a panel data regression model including observations from treatment 2 and treatment 5 , with $\mathrm{S} / \mathrm{T}$ as the dependent variable, the coefficient of the DT5 dummy is not significant, even when controlling for the tax rate.
} 
government to adopt this system starting with January $1^{\text {st }}, 2019 .^{14}$

In addition, sanction rates tend to be lower in treatments in which the tax authority can communicate to taxpayers, yet subjects did not make extensive use of the communication channel. This could be explained by the limited size of the message, or by the youth of the participants.

Last, the comparison of sanction rates when the tax-authority is played by a human subject and when the tax decision is made by the computer suggests that dissatisfaction with taxes is independent of the responsibility attribution mechanism, and might just reveal anger with transfers of income to a third party.

All caveats specific to experimental research apply to this simple experiment. On the other hand, our results call attention to an important behavioral dimension of taxation. If the tax collection system has an impact on dissatisfaction with taxation, then it might influence tax acceptance and tax compliance. This second stage is worth being analyzed in subsequent research.

Acknowledgement 1 The authors would like to thank two anonymous referees and the editors of this special issue for their suggestions and remarks that helped them improving this analysis.

\section{References}

Ben-Shakhar G., Bornstein G., Hopfensitz A. and van Winden F. [2007], Reciprocity and emotions in bargaining using physiological and self-report measures. Journal of Economic Psychology, 28, 3: 314-323.

Bosman, R., Hennig-Schmidt H. and van Winden F. [2017], Emotion at stake - The role of stake size and emotions in a power-to-take game experiment in China with a comparison to Europe, Games 8, 1: 17 pages.

Bosman, R., Sutter M. and van Winden, F. [2005], The impact of real effort and emotions in the power-to-take game, Journal of Economic Psychology, 26, 3: 407-429

Bosman, R. and van Winden F. [2002], Emotional hazard in a power-to-take experiment, Economic Journal, 112, 476: 147-169.

Chetty, R., Looney A. and Kroft, K. [2009], Salience and taxation: Theory and evidence, American Economic Review, 99, 4: 1145-77.

Christian, R. C. and Alm J. [2014], Empathy, sympathy, and tax compliance. Journal of Economic Psychology, 40: 62-82.

Falk, A. and Fischbacher U. [2005], Driving forces behind informal sanctions, Econometrica, 73, 6: 2017-2030.

\footnotetext{
14 In February 2019, Elabe, a survey research institute, revealed that $74 \%$ of the surveyed persons expressed a positive opinion about the reform. The survey included a representative sample of 1001 French citizens. See "Atterisage reussi pour l'impot à la source", Elabe. https://elabe.fr/prelevement-source-vague3/.
} 
FDF [2016], Federal, Cantonal and Communal Taxes, an Outline of the Swiss Tax System, Federal Department of Finance, Swiss Federal Tax Administration, Online at: www.estv.admin.ch.

Fehr, D., Hakimov R. and Kübler D. [2015], The willingness to pay-willingness to accept gap: A failed replication of Plott and Zeiler, European Economic Review, 78, 120-128.

Fehr, E. and Gächter, S. [2000], Cooperation and punishment in public goods experiments, American Economic Review, 90, 4: 980-994.

Fischbacher U. [2007], z-Tree: Zurich toolbox for ready-made economic experiments, Experimental Economics, 10, 2: 171-178.

Fischbacher U. and Utikal V. [2013], On the acceptance of apologies, Games and Economic Behavior, 82: 592-608.

Galeotti, F., 2015. Do negative emotions explain punishment in power-to-take game experiments?, Journal of Economic Psychology, 49: 1-14.

Hallsworth, M., List, J A., Metcalfe, R. D. and Vlaev, I. [2014], The behavioralist as tax collector: Using natural field experiments to enhance tax compliance, NBER Working Paper 20007.

Kahneman, D., Knetsch, J.L. and Thaler R. H. [1990], Experimental tests of the endowment effect and the Coase theorem, Journal of Political Economy, 98, 6: 1325-1348.

Kahneman, D. and Tversky, A. [1979], Prospect theory: An analysis of decision under risk, Econometrica, 47, 2: 263-291.

Kirchler, E. and Hoelzl, E. [2018], Economic Psychology: An Introduction, Cambridge University Press.

Kirchler E. [2007], The Economic Psychology of Tax Behaviour, Cambridge University Press.

Morewedge, C. K. and Giblin, C. E. [2015], Explanations of the endowment effect: an integrative review, Trends in Cognitive Sciences, 19, 6: 339-348.

OECD [2009], Withholding and Information Reporting Regimes for Small/Mediumsized Businesses and Self-employed Taxpayers, Information note of the Forum on Tax Administration Compliance Sub-group, OECD, Paris, http://www.oecd.org/tax/administration/48449751.pdf.

Onu, D. and Oats L. [2015], Paying tax is part of life: Social norms and social influence in tax communications, Journal of Economic Behavior and Organization, Available online, http://dx.doi.org/10.1016/j.jebo.2015.11.017.

Plott, C. R. and Zeiler, K. [2007], Exchange asymmetries incorrectly interpreted as evidence of endowment effect theory and prospect theory?, American Economic Review 97, 4 14491466 .

Reuben, E. and van Winden F. [2008], Social ties and coordination on negative reciprocity: The role of affect, Journal of Public Economics 92, 1-2: 34-53.

Robben, H., Webley, P., Weigel R., Wärneryd K-E., Kinsey K., Hessing, D., Alvira Martin F., Elffers H., Wahlund R., van Langenhove L., Long S. and Scholtz T. [1990], Decision frame and opportunity as determinants of tax cheating: An international experimental study, Journal of Economic Psychology, 11, 3: 341-364.

Sutter, M., Bosman R., Kocher M. G. and van Winden, F. [2009], Gender pairing and bargaining-Beware the same sex!, Experimental Economics 12, 3: 318-331. 
van Winden, F. [2015], Political economy with affect: On the role of emotions and relationships in political economics, European Journal of Political Economy, 40-B: 298-311.

Weigel R. H., Hessing D.J. and Elffers, H. [1987], Tax evasion research: A critical appraisal and theoretical model, Journal of Economic Psychology, 8, 2: 215-235.

Yechiam E., Ashby N.J.S. and Pachur, T. [2017], Who's biased? A meta-analysis of buyerseller differences in the pricing of lotteries, Psychological Bulletin, 143, 5: 543. 


\section{Online appendix}

Discontent with taxes and the timing of taxation: Experimental evidence

R. Vranceanu, A. Sutan, D. Dubart

\section{A Instructions}

\section{Instructions for treatement T3}

\section{Slide 1. Introduction}

Good morning.

Thank you for participating to this experiment.

Please read carefully these instructions, and should you have any question, please raise your hand and the administrator will join you so that you can ask him/her the question.

Cellular phones must be turned off. Please do not try to communicate between you. If such a thing happens you will be asked to leave the room.

Your compensation for your participation will be provided in cash at the end of the session.

Payoffs in the experiment are denominated in Experimental Currency Units (ECU).

At the outset of the game each subject receives 50 ECUs as show up fee. The additional compensation depends on his/her performance in the experiment. The session involves three identical round. At the end of the experiment, the computer will draw at random one of the round, and the ECU payoff will be paid to you in cash.

The exchange rate is $10 \mathrm{ECU}=1$ euro.

\section{Slide 2. The description of the experiment}

You will play the same game three times. Each time, you will be paired with another player, chosen at random in the population of students present in the room. Pairs will change from one round to another. Anonymity is strictly guaranteed.

Each pair includes a Player A and a Player B

1st step. At the beginning of each round the computer draws an integer $Y$ in the interval $[50,100]$.

2nd step. Agent A is informed that he received this endowment 
3rd step. Agent B learns the amount $Y$ received by agent A and can take an amount $T$ in the interval $[0, Y]$.

4th step. Agent A learns the amount $T$ taken by agent B and can impose a fine $S$ on agent B. The fine can vary between $[0, T]$. For each 1 ECU of fine, the Agent A will bear a loss of 0.2 ECUs.

Thus, at the end of the round, the payoff of Agent A is $(Y-T-0.2 S)$, where $T$ is chosen by Agent B and $S$ is chosen by Agent A. The payoff of Agent B is $(T-S)$, where $S$ is the sanction decided by Agent A.

\section{Slide 3A. "You are Agent A"}

Following the Computer draw in the interval $[50,100]$ you get the endowment $Y=\ldots$ ECUs.

At the next stage, Agent B can take an amount $T$ in the interval $[0, Y]$.

You will be allowed to impose on him a fine $S$ in the interval $[0, T]$. This sanction will reduce the payoff of Agent B. Your own payoff will be reduced by 0.2 ECU for each 1 ECU of fine.

- What is your guess about the amount $T$ that Agent B will take from you ? Fill in this box [......

You will be rewarded for this guess according to the function $G=20 /\left[1+(T-E)^{2}\right]$, where $E$ is your guess of $T$. This expression means that you will win the most (20 ECUS) if the guess is equal to the actual amount.

\section{Slide 3B. "You are Agent B".}

Following the Computer draw in the interval $[50,100]$, Agent A received the amount $Y=$ ...ECUs.

You can take an amount $T$ in the interval $[0, Y]$, after having answered to an intermediary question.

Following your decision, Agent A will be able to impose on you a fine $S$ in the interval $[0, T]$. Each 1 ECU of fine will cost him/her 0.2 ECUs.

- What is your guess about the sanction $S$ that Agent A will impose on you ? Fill in this box $[\ldots]$

You will be rewarded for this guess according to the function $G=20 /\left[1+(S-Z)^{2}\right]$, where $Z$ 
is your guess of $S$. This expression means that you will win the most (20 ECUS) if the guess is equal to the actual amount.

- What is the amount you want to take from Agent A ? Fill in this box [...]

$==\mathrm{=}=\mathrm{=}=\mathrm{=}=\mathrm{=}=\mathrm{=}=\mathrm{=}=\mathrm{=}$

- You can send a max 80 characters message to Agent A. Fill in this box [........ $..]^{15}$

\section{Slide 4. You are Agent A}

Following the random draw of the Computer you got $Y=\ldots$ ECUs

Agent $\mathrm{B}$ has taken the amount $T=\ldots$

You thus will get the difference $D=\ldots$

He/she sent you this message $[\ldots \ldots \ldots \ldots \ldots . . . .$.

You can impose on him/her a fine $S$, in the interval $[0 . . T]$. This fine will reduce the amount available for Agent B and will cost you 0.2 ECU per each ECU charged.

What is the amount of the fine $S$ you want to charge ? Fill in this box [...]

\section{Slide 5A. Payoffs. You are Agent A}

You received $Y=\ldots$

Agent B took $T=\ldots$

Your guess of $T$ was $E=\ldots$

You required a fine $S=\ldots$

Your final gain for this round is ...

Slide 5B. Payoffs. You are Agent B

Agent A received $Y=\ldots$

You took $T=\ldots$

Your guess of $S$ was $Z=\ldots$

The fine you received was $S=\ldots$

Your final gain for this round is ...

15 The message box is not available in treatments $\mathrm{T} 1, \mathrm{~T} 2$ and $\mathrm{T} 5$. 


\section{Instructions for treatment T4}

\section{Slide 1. Introduction}

Identical T3

\section{Slide 2. The description of the experiment}

You will play the same game three times. Each time, you will be paired with another player, chosen at random in the population of students present in the room. Pairs will change from one round to another. Anonymity is strictly guaranteed.

Each pair includes a Player A and a Player B

1st step. At the beginning of each round the computer draws an integer $Y$ in the interval $[50,100]$

2nd step. Agent B learns this amount and can take an amount $T$ in the interval $[0, Y]$. He knows that the difference will go to Agent A.

3rd step. Agent $\mathrm{A}$ is informed about $Y$ and about $T$. He thus receives the difference $(Y-T)$.

4th step. Agent A can impose a fine $S$ on agent B. The fine can vary between $[0, T]$. For each 1 ECU of fine, the Agent A will bear a loss of 0.2 ECUs.

Thus, at the end of the round, the payoff of Agent A is $(Y-T-0.2 S)$, where $T$ is chosen by Agent B and $S$ is chosen by Agent A. The payoff of Agent B is $(T-S)$, where $S$ is the sanction decided by Agent A.

\section{Slide 3. "You are Agent B".}

The Computer drew in the interval $[50,100]$ the amount $Y=\ldots$ ECUs.

You can take an amount $T$ in the interval $[0, Y]$, after having answered to an intermediary question. The difference $[Y-T]$ will be given to Agent A.

Agent A will be informed about $Y$ and $T$. He will be able to impose on you a fine $S$ in the interval $[0, T]$. The fine will reduce you own payoff. Each 1 ECU of fine will cost 0.2 ECU to Agent A.

- What is your guess about the sanction $S$ that Agent A will impose on you? Fill in this box [... 
You will be rewarded for this guess according to the function $G=20 /\left[1+(S-Z)^{2}\right]$, where $Z$ is your guess of $S$. This expression means that you will win the most (20 ECUS) if the guess is equal to the actual amount.

- What is the amount you want to take from Agent A ? Fill in this box [...]

- You can send a max 80 character message to Agent A. Fill in this box [.............

\section{Slide 4. You are Agent A}

The Computer drew $Y=\ldots$ ECUs

Agent B has taken the amount $T=\ldots$

You received the difference $(Y-T)=\ldots$

$\mathrm{He} /$ she sent you this message $[\ldots \ldots \ldots . . . .$.

You can impose on him/her a fine $S$, in the interval $[0, T]$. This fine will reduce the amount available for Agent B and will cost you 0.2 ECU per ECU charged.

What is the amount of the fine $S$ you want to charge ? Fill in this box [...]

\section{Slide 5A. Payoffs. You are Agent A}

The Computer drew $Y=\ldots$

Agent B took $T=\ldots$

You imposed on Agent B a fine $S=\ldots$

Your final gain for this round is ...

\section{Slide 5B. Payoffs. You are Agent B}

The Computer drew $Y=\ldots$

You took $T=\ldots$

Your guess of $S$ was $Z=\ldots$

The fine you received was $S=\ldots$

Your final gain for this round is.... 


\section{B Descriptive statistics}

Table 9 presents the mean values (and standard errors) for the main variables across the five treatments.

\begin{tabular}{|l|l|l|l|l|l|}
\hline & Tr. 1 & Tr. 2 & Tr. 3 & Tr. 4 & Tr. 5 \\
\hline Nb. obs & 90 & 108 & 108 & 108 & 81 \\
\hline Endowment $Y$ & $74.22(13.87)$ & $75.62(14.36)$ & $74.39(14.49)$ & $75.63(14.64)$ & $72.94(13.65)$ \\
\hline Tax $T$ & $50.73(24.28)$ & $40.88(22.59)$ & $46.02(21.47)$ & $43.01(21.09)$ & $37.17(21.83)$ \\
\hline Sanction $S$ & $29.08(28.74)$ & $12.94(20.47)$ & $19.00(23.58)$ & $11.87(23.43)$ & $7.99(13.68)$ \\
\hline Guess sanction & $37.35(27.80)$ & $13.68(19.82)$ & $27.22(27.09)$ & $15.55(19.9)$ & - \\
\hline Guess tax & $50.64(21.33)$ & - & $45.86(18.90)$ & - & - \\
\hline
\end{tabular}

Table 9: Mean values of key variables by treatment (s.e. within parantheses)

\section{The behavior of Agent B (the tax-authority)}

The behavior of Agent B can further be analyzed by means of a "tax equation", which relates the individual tax rate $T / Y$ to various covariates as defined in the main text.

Table 10 presents the output of the random effect, panel regression models, which account that every individual $i$ in the role of Agent B made three tax choices, at three distinct periods. The benchmark is $\mathrm{T} 1$.

\begin{tabular}{|l|l|l|l|}
\hline & Model 1 & Model 2 & Model 3 \\
\hline DT2 & $-0.149^{* * *}(0.04)$ & $-0.149^{* * *}(0.04)$ & $-0.149^{* * *}(0.04)$ \\
\hline DT3 & $-0.058(0.04)$ & $-0.058(0.04)$ & $-0.042(0.04)$ \\
\hline DT4 & $-0.114^{* * *}(0.04)$ & $-0.114^{* * *}(0.04)$ & $-0.095^{* *}(0.04)$ \\
\hline P2 & - & $0.071^{* *}(0.03)$ & $0.071^{* *}(0.03)$ \\
\hline P3 & - & $0.106^{* * *}(0.03)$ & $0.106^{* * *}(0.03)$ \\
\hline DI & - & $-0.032(0.04)$ \\
\hline Constant & $0.683^{* * *}(0.03)$ & $0.624^{* * *}(0.03)$ & $0.624^{* * *}(0.03)$ \\
\hline Nb. obs. & 414 & 414 & 414 \\
\hline R-sq (between) & 0.120 & 0.120 & 0.127 \\
\hline Legend: ${ }^{* *}$ significant at 1\%; ${ }^{* *}$ significant at 5\%; Std. err. within parantheses. \\
\hline
\end{tabular}

Table 10: The Tax Equation

As revealed by the significant coefficients of DT2 and DT4, we remark that the tax rate is systematically lower in T2 and T4 (the PAYE tax collection system) compared to T1 and T2.

Contrary to sanction rates, tax rates increase over rounds (the round dummies are positive and significant). 
Finally, Table 11 shows the guess of the sanction rate, and the actual sanction rate by treatment. Across all treatments, at 0.03 the agregate error is relatively small, yet with substantial variance in individual data (stand. dev. $=0.50)$.

\begin{tabular}{|l|l|l|l|l|}
\hline & Treatment 1 & Treatment 2 & Treatment 3 & Treatment 4 \\
\hline S/T & $0.53(0.05)$ & $0.30(0.04)$ & $0.38(0.04)$ & $0.23(0.04)$ \\
\hline Guess of S/T & $0.59(0.04)$ & $0.30(0.04)$ & $0.42(0.04)$ & $0.26(0.04)$ \\
\hline Difference guess - sanction & $0.06(0.05)$ & $0.00(0.05)$ & $0.04(0.05)$ & $0.03(0.05)$ \\
\hline
\end{tabular}

Table 11: Mean sanction rate and guessed sanction rate by treatment (s.e. within parantheses) 


\section{I \\ ESSEC \\ BUSINESS SCHOOL}

ESSEC Business School

3 avenue Bernard-Hirsch

CS 50105 Cergy

95021 Cergy-Pontoise Cedex

France

Tel. +33 (0)134433000

www.essec.edu

\section{ESSEC Executive Education}

CNIT BP 230

92053 Paris-La Défense

France

Tel. +33 (0)1 46924900

www.executive-education.essec.edu

\section{ESSEC Asia-Pacific}

5 Nepal Park

CONTACT

Singapore 139408

RESEARCH CENTER

Tel. +65 68849780

research@essec.edu

\section{www.essec.edu/asia}

ESSEC | CPE Registration number 200511927D

Period of registration: 30 June 2017 - 29 June 2023

Committee of Private Education (CPE) is part of SkillsFuture Singapore (SSG)

\section{ESSEC Africa}

Plage des Nations - Golf City

Route de Kênitra - Sidi Bouknadel (Rabat-Salê)

Morocco

Tel. +212 (0)5 37824000

www.essec.edu 